\title{
Five-antituberculosis Drug-resistance Genes Detection Using Array System
}

\author{
Yasuo Shimizu ${ }^{1 *}$, Kunio Dobashi², Yoko Yoshikawa ${ }^{3}$, Shigeki Yabe ${ }^{4}$, Seiichi Higuchi', \\ Yoko Koike $^{1}$, Yoshihiro Mita ${ }^{1}$, Mitsuyoshi Utsugi ${ }^{1}$, Katsuaki Endou ${ }^{1}$, Kouichi Takahashi ${ }^{5}$, \\ Satoru Watanabe ${ }^{6}$, Ryusei Saito ${ }^{6}$, and Masatomo Mori ${ }^{1}$ \\ ${ }^{1}$ Department of Medicine and Molecular Science, Gunma University Graduate School of Medicine, Maebashi, \\ Gunma 371-8511, Japan \\ ${ }^{2}$ Gunma University School of Health Sciences, Maebashi, Gunma 371-8511, Japan \\ ${ }^{3}$ Research \& Development Center, Nisshinbo Industry, Inc., Chiba, Chiba 267-0056, Japan \\ ${ }^{4}$ Department of Laboratory Medicine and Clinical Laboratory Center, Gunma University Graduate School \\ of Medicine, Maebashi, Gunma 371-8511, Japan \\ ${ }^{5}$ Matsuida Hospital, Gunma, Annaka, Gunma 379-0021, Japan \\ ${ }^{6}$ Nishigunma National Hospital, Shibukawa, Gunma 377-0027, Japan
}

Received 12 October, 2007; Accepted 29 October, 2007

\begin{abstract}
Summary Detection of resistance to drugs for Mycobacterium tuberculosis takes about two months from the sample collection using culture-based methods. To test a rapid method for detection of resistance for five antituberculosis drugs using DNA microarray and to examine its potential for clinical use, we employed a DNA microarray for detection of seven mutations genes related to resistance of five kinds of antituberculous drugs using Mycobacterium tuberculosis DNA isolated from sputum. The results of microarray analysis were compared with the results of a standard culture method of Lowenstein-jensen drug sensitivity testing system. DNA microarray analysis showed a high sensitivity $(>90 \%)$ for all five drugs. Specificity of rifampicin and ethambutol were nearly $90 \%$, however specificity of isoniazid $(60 \%)$ and kanamycin $(67 \%)$ were not enough. The amount of Mycobacterium tuberculosis DNA required for microarray analysis corresponded to at least 1-9 Acid-Fast Bacilli per 10 fields by carbolfuchsin staining. DNA microarray analysis appears to be useful for estimation of drug resistances, nevertheless its limitations. To minimize misunderstanding, it is necessary to confirm the number of bacilli in the sputum, and culture method is needed for comparison when use the PCR-based array system.
\end{abstract}

Key Words: multidrug resistance, rapid diagnosis, Mycobacterium tuberculosis, DNA microarray

\section{Introduction}

The prevalence of drug-resistant tuberculosis continues to increase around the world. According to a survey of resistance to first-line antituberculous drugs performed in 1994

\footnotetext{
*To whom correspondence should be addressed.

Tel: +81-27-220-8123 Fax: +81-27-220-8136

E-mail: yasuos@med.gunma-u.ac.jp
}

by the World Health Organization and the International Union Against Tuberculosis and Lung Disease, multi drugresistant tuberculosis (MDR-TB) was found in all 35 countries investigated. In 2000, MDR-TB was detected in 72 countries, and MDR-TB was also serious problem on immuno-compromised host [1]. With current methods based on culture, it takes about two months after collection of sputum to obtain the result of drug resistance test, i.e. after sample collection, the tuberculosis organisms needed to growth in culture, and then, the part of organisms grown on 
its culture are put on another drug sensitivity test culture. At the start of therapy, empirical therapy with several antituberculous drugs are needed, and if failed to cure due to drug resistance of $\mathrm{TB}$, the duration of hospitalization would be quite long. Therefore, it would be beneficial to treat drugs resistant-TB more effectively. In particular, the rapid detection of drug resistance would be expected to overcoming this problem. Several new technologies have been developed for the rapid assessment of drug resistance using high density DNA probe [2], solid-phase sequence scanning [3] and invader assay using real-time PCR [4]. Although these methods have proven effective, these method need for an expensive microarray scanner to detect fluorescence, or sequencer. The INNO-LiPA Rif. TB ${ }^{\circledR}$ (LiPA) is a commercial line probe assay using nitrocellulose paper strips, and adapted to clinical setting in developed countries [5]. This system is used for detect genetic mutation in the rpoB gene region related to Rifampicin (RFP) resistance. There is no method for simultaneously rapid detection of five kinds of antituberculosis drug resistances in practical medicine. Also, the current rapid diagnosis systems have not yet become widely available, and the rapid detection of drug resistances remains a major public health problem.

From the study of $M$. tuberculosis DNA, it has become clear that missense mutations play a role in drug resistance. Mutations of the inhA [6] and KatG [7] genes of M. tuberculosis are involved in about $80 \%$ of resistance to isoniazid (INH), mutations of the rpoB gene control about $95 \%$ of resistance to rifampicin (RFP) [8], mutations of the $r r s$ and rps $L$ genes are concerned with about $80 \%$ of resistance to streptomycin (SM), mutations of the rrs gene cause $70 \%$ of resistance to kanamycin (KM), and mutations of the $e m b B$ gene produce about $70 \%$ of resistance to ethambutol (EB) [9]. On the basis these seven genes related to antituberculous drug resistance, we developed a DNA microarray that could detect mutations of all seven genes rapidly in one day and simply. Array signals were obtained by a peroxidase reaction, and were detected easily using an office scanner, as previously reported [10]. There have been no reports about detection of resistance to five antituberculous drugs at once.

In this study, we tested the DNA microarray for detection of mutations of the seven genes mediating resistance to the above-mentioned five drugs using M. tuberculosis DNA isolated from sputum. The results of microarray analysis were compared with the drug resistance data obtained using culture method, and we assessed the accuracy of detecting of drug resistance with the microarray, and also we try to clarify the limitations of DNA microarray use in clinical setting.

\section{Method}

Sample collection and extraction of M. tuberculosis DNA Sputum samples $(n=48)$ were obtained from 48 tubercu- losis patients with pulmonary tuberculosis. The diagnosis of $M$. tuberculosis infection was based on radiography, smear of sputum, and PCR using the Amplicore method for $M$. tuberculosis (Roche Diagnostic Systems, Somerville, NJ), and culture-based method of Lowenstein-jensen standard culture-based drug sensitivity testing system raised in recommended drug concentrations for drug susceptibility testing as described [11]. Sputum samples were homogenized with semi-alkaline proteinase (Sputazyme, Kyokuto Pharmaceutical, Co. Ltd., Japan) according to the manufacturer's instructions. Homogenized sputum was treated by the NALC-NaOH method [11], and then DNA was isolated using a specimen preparation kit (COBAS AMPLICORE ${ }^{\mathrm{TM}}$, Roche Diagnostics, NJ). This study was conducted according to the Declaration of Helsinki, and all patients gave written informed consent before enrollment, and was approved by the Human Research Committee of Gunma University.

\section{DNA amplification}

Fragments of drug resistance-related genes (rpoB, inhA, $k a t G, r p s L, r r s$, and $e m b B$ ) containing drug-sensitive or drug-resistant polymorphisms were amplified by multiplex PCR using 18 sets of primers. The rrs gene was also amplified in the same tube to distinguish $M$. tuberculosis from $M$. avium. The target genes, amplicon sizes, and primer sequences are listed in Table $1 \mathrm{a}$, and the relationship between target gene, primer, and mutation site is shown in Table $1 \mathrm{~b}$. These 18 primers detect known mutations in the followings of the rpoB, inhA, katG, rpsL, rrs, and emb $B$ genes (Table 2). PCR amplification was performed by the following procedure. The reaction mixture $(19 \mu \mathrm{l})$ contained $10 \mathrm{mM}$ Tris- $\mathrm{HCl}$ (pH 8.3), $1.5 \mathrm{mM} \mathrm{MgCl} 2,200 \mathrm{nM}$ of each dNTP, $500 \mathrm{nM}$ of each primer, 2.5 U of AmpliTaq Gold (Applied Biosystems Japan Ltd., Japan), and $1 \mu \mathrm{l}$ of genomic DNA. The reaction mixture was preheated at $95^{\circ} \mathrm{C}$ for $9 \mathrm{~min}$, followed by 50 cycles of denaturation at $94^{\circ} \mathrm{C}$ for $30 \mathrm{~s}$, annealing and extension at $64^{\circ} \mathrm{C}$ for $1 \mathrm{~min}$, with postcycling extension at $72^{\circ} \mathrm{C}$ for $10 \mathrm{~min}$ using a DNA engine thermal cycler (MJ Research Inc., Waltham, MA).

\section{DNA microarray}

DNA oligomers about 20 to 24 bp long were immobilized on glass slides [10]. The arrangement of mutation detection sites on the DNA microarray is shown in Table 1c. The microarray field was largely divided into isoniazid (INH), RFP, SM, KM, and EB resistance detection fields, as well as a $M$. tuberculosis and $M$. avium complex detection field. The oligomers spotted in the extreme left hand lane contained the wild-type DNA sequences, while the other lanes contained the mutants. If there was no signal in the M. tuberculosis detection field, the sample did not contain M. tuberculosis and the test was invalid even if positive 
Table 1a. Forward and Reverse Primers for Drug Resistance Genes.

\begin{tabular}{|c|c|c|c|c|c|}
\hline amplicon size & target gene & primer & forward primer sequence $\left(5^{\prime}-3{ }^{\prime}\right)$ & primer & reverse primer sequence $\left(5^{\prime}-3^{\prime}\right)$ \\
\hline $71 \mathrm{bp}$ & inhA & $1 \mathrm{~F}$ & CGT GGA CAT ACC GAT TTC G & $1 \mathrm{R}$ & 5'biotin-TCA GTG GCT GTG GCA GTC A \\
\hline $186 \mathrm{bp}$ & KatG & $2 \mathrm{~F}$ & GGT CGC GAC CAT CGA CGT TG & $2 \mathrm{R}$ & 5'biotin-AAC CGC TGC ATG CCG C \\
\hline $79 \mathrm{bp}$ & KatG & $3 \mathrm{~F}$ & GCT TAA CAG CAG GCC CGA C & $3 \mathrm{R}$ & 5'biotin-CTT GCC GTA CTT CTT CTT GAC C \\
\hline $142 \mathrm{bp}$ & KatG & $4 \mathrm{~F}$ & GGT CAA GAA GAA GTA CGG CAA G & $4 \mathrm{R}$ & 5'biotin-AAT AgA CCT CAT Cgg gCT C \\
\hline $50 \mathrm{bp}$ & KatG & $5 \mathrm{~F}$ & GCG GTC ACA CTT TCG GTA & $5 \mathrm{R}$ & 5'biotin-GAC CAG ATC GGC CGG G \\
\hline $119 \mathrm{bp}$ & KatG & $6 \mathrm{~F}$ & AAG AGC TCG TAT GGC ACC & $6 \mathrm{R}$ & 5'biotin-TCG CCG TAC AGG ATC T \\
\hline $102 \mathrm{bp}$ & KatG & $7 \mathrm{~F}$ & GCC GAG ATT GCC AGC CTT & $7 \mathrm{R}$ & 5'biotin-GCT ACC ACG GAA CGA CGA \\
\hline $93 \mathrm{bp}$ & KatG & $8 \mathrm{~F}$ & GAA TCC TTT GCC GTG CTG GAG & $8 \mathrm{R}$ & 5'biotin-GTC GAG CAG CAT GTA CTC \\
\hline $158 \mathrm{bp}$ & negative control & $9 \mathrm{~F}$ & CTC TTC GGA GAT ACT CGA GTG & $9 \mathrm{R}$ & 5'biotin-CCG CGG GCT CAT CCC AC \\
\hline $124 \mathrm{bp}$ & rpoB & $10 \mathrm{~F}$ & GCC GCG ATC AAG GAG TTC & $10 \mathrm{R}$ & 5'biotin-CAC GTG ACA GAC CGC CGG \\
\hline $153 \mathrm{bp}$ & rrs & $11 \mathrm{~F}$ & GGT TCT CTC GGA TTG ACG GTA G & $11 \mathrm{R}$ & 5'biotin-AGC CGT GAG ATT TCA CGA ACA AC \\
\hline $99 \mathrm{bp}$ & rrs & $12 \mathrm{~F}$ & GGT TTC CTT CCT TGG GAT C & $12 \mathrm{R}$ & 5'biotin-GGC CCC CGT CAA TTC CTT \\
\hline $63 \mathrm{bp}$ & rpsL & $13 \mathrm{~F}$ & TAT GCA CCC GCG TGT ACA & $13 \mathrm{R}$ & 5'biotin-GGG CAA CCT TCC GAA GCG \\
\hline $106 \mathrm{bp}$ & rpsL & $14 \mathrm{~F}$ & GAG GTC ACG GCG TAC ATT & $14 \mathrm{R}$ & 5'biotin-TCT TGT AGC GCA CAC CAG \\
\hline $65 \mathrm{bp}$ & rrs & $15 \mathrm{~F}$ & CTT GTA CAC ACC GCC CGT & $15 \mathrm{R}$ & 5'biotin-CGA GGG TTA GGC CAC TGG \\
\hline $76 \mathrm{bp}$ & rrs & $16 \mathrm{~F}$ & CCA GTG GCC TAA CCC TCG & $16 \mathrm{R}$ & 5'biotin-CGG CTA CCT TGT TAC GAC \\
\hline $92 \mathrm{bp}$ & embB & $17 \mathrm{~F}$ & GTG GTG ATA TTC GGC TTC CT & $17 \mathrm{R}$ & 5'biotin-TGG TCG GCG ACT CGG GC \\
\hline $80 \mathrm{bp}$ & embB & $18 \mathrm{~F}$ & CAA CTA TTT CCG CTG GTT CG & $18 \mathrm{R}$ & 5'biotin-TGA CAT GGG TCA TCA GCG \\
\hline
\end{tabular}

Drug resistance genes were $i n h A$ and $K a t G(\mathrm{INH}), r p o B$ (RFP), $r r s$ and $r p s L(\mathrm{SM}), r r s(\mathrm{KM})$, and $e m b B(\mathrm{~EB})$.

Table 1b. Relations between Primer Numbers, Drug Resistance Genes and Mutation Sites.

\begin{tabular}{|c|c|l|}
\hline primer & target gene & \multicolumn{1}{|c|}{ mutation } \\
\hline 1 & inhA & $1022 \mathrm{~A} / \mathrm{G}, 1023 \mathrm{C} / \mathrm{T}, 1030 \mathrm{~T} / \mathrm{A}, 1030 \mathrm{~T} / \mathrm{G}$ \\
\hline 2 & KatG & $281 \mathrm{~A} / \mathrm{C}, 322,324 \mathrm{CC} / \mathrm{GG}, 369 \mathrm{G} / \mathrm{C}$ \\
\hline 3 & KatG & $412 \mathrm{~A} / \mathrm{C}, 413 \mathrm{~A} / \mathrm{G}, 419 \mathrm{G} / \mathrm{A}, 425 \mathrm{~A} / \mathrm{C}$ \\
\hline 4 & KatG & $479 \mathrm{C} / \mathrm{T}, 514 \mathrm{G} / \mathrm{A}, 539 \mathrm{C} / \mathrm{A}$ \\
\hline 5 & KatG & $823 \mathrm{~A} / \mathrm{G}$ \\
\hline 6 & KatG & $944 \mathrm{G} / \mathrm{A}, 944 \mathrm{G} / \mathrm{C}, 944,945 \mathrm{GC} / \mathrm{CA}, 982 \mathrm{~T} / \mathrm{G}$ \\
\hline 7 & KatG & $1431 \mathrm{G} / \mathrm{A}$ \\
\hline 8 & KatG & $1778 \mathrm{G} / \mathrm{A}$ \\
\hline 9 & negative control & - \\
\hline 10 & rpoB & $180 \mathrm{C} / \mathrm{A}, 180 \mathrm{C} / \mathrm{G}, 180 \mathrm{C} / \mathrm{T}, 181 \mathrm{~A} / \mathrm{C}, 190 \mathrm{~A} / \mathrm{T}, 191 \mathrm{C} / \mathrm{A}, 201 \mathrm{C} / \mathrm{T}, 208 \mathrm{C} / \mathrm{T}, 218,220,22 \mathrm{CAA} / \mathrm{GCC}, 219 \mathrm{C} /$ \\
& & $\mathrm{A}, 219 \mathrm{C} / \mathrm{G}, 219 \mathrm{C} / \mathrm{T}, 220 \mathrm{~A} / \mathrm{C}, 220 \mathrm{~A} / \mathrm{G}, 221 \mathrm{C} / \mathrm{A}, 221 \mathrm{C} / \mathrm{G}, 235 \mathrm{C} / \mathrm{G}, 235 \mathrm{C} / \mathrm{T}, 241 \mathrm{~T} / \mathrm{C}$ \\
\hline 11 & $\mathrm{rrs}$ & $505 \mathrm{C} / \mathrm{T}, 526 \mathrm{C} / \mathrm{T}, 527 \mathrm{~A} / \mathrm{C}, 527 \mathrm{~A} / \mathrm{T}, 530 \mathrm{C} / \mathrm{T}$ \\
\hline 12 & $\mathrm{rrs}$ & $920 \mathrm{C} / \mathrm{A}, 920 \mathrm{C} / \mathrm{G}, 921 \mathrm{~A} / \mathrm{G}, 893 \mathrm{G} / \mathrm{A}$ \\
\hline 13 & $\mathrm{rpsL}$ & $134 \mathrm{~A} / \mathrm{G}, 134 \mathrm{~A} / \mathrm{C}$ \\
\hline 14 & $\mathrm{rpsL}$ & $269 \mathrm{~A} / \mathrm{C}, 269 \mathrm{~A} / \mathrm{G}, 269 \mathrm{~A} / \mathrm{T}$ \\
\hline 15 & $\mathrm{rrs}$ & $1423 \mathrm{~A} / \mathrm{G}, 1424 \mathrm{C} / \mathrm{A}, 1424 \mathrm{C} / \mathrm{T}$ \\
\hline 16 & $\mathrm{rrs}$ & $1516 \mathrm{G} / \mathrm{T}$ \\
\hline 17 & $\mathrm{embB}$ & $7868 \mathrm{~A} / \mathrm{G}, 7868 \mathrm{~A} / \mathrm{C}, 7870 \mathrm{G} / \mathrm{A}, 7870 \mathrm{G} / \mathrm{T}, 7870 \mathrm{G} / \mathrm{C}$ \\
\hline 18 & $\mathrm{embB}$ & $7940 \mathrm{~T} / \mathrm{G}$ \\
\hline
\end{tabular}

Drug resistance genes were $i n h A$ and $K a t G(\mathrm{INH}), r p o B$ (RFP), $r r s$ and $r p s L(\mathrm{SM}), r r s$ (KM), and embB (EB).

signals were detected in the drug resistance fields. If the wild-type oligomer did not show a signal and mutants yielded signals on the DNA microarray, drug resistance was diagnosed.

\section{Hybridization and signal detection}

The PCR product $(5 \mu \mathrm{l})$ was mixed with $20 \mu \mathrm{l}$ of hybridization solution, and then the mixture was denatured at $98^{\circ} \mathrm{C}$ for $5 \mathrm{~min}$ and chilled on ice for $1 \mathrm{~min}$ before being used as biotin-labeled DNA probes. Subsequently, the mixture was 
Table 1c. Arrangements on Microarray for Drug Resistance Genes

\begin{tabular}{|c|c|c|c|c|c|c|c|c|c|c|c|c|c|c|c|c|c|c|}
\hline $\mathrm{B}$ & $\mathrm{W}$ & $1022 \mathrm{~A} / \mathrm{G}$ & $1023 \mathrm{C} / \mathrm{T}$ & & INH & $\mathrm{B}$ & $\mathrm{B}$ & $\mathrm{W}$ & $180 \mathrm{C} / \mathrm{A}$ & $180 \mathrm{C} / \mathrm{G}$ & $180 \mathrm{C} / \mathrm{T}$ & $181 \mathrm{~A} / \mathrm{C}$ & & & & & RFP & $\mathrm{B}$ \\
\hline & W & $1030 \mathrm{~T} / \mathrm{A}$ & $1030 \mathrm{~T} / \mathrm{G}$ & & & & & W & $190 \mathrm{~A} / \mathrm{T}$ & $191 \mathrm{C} / \mathrm{A}$ & & & & & & & & \\
\hline & W & $281 \mathrm{~A} / \mathrm{C}$ & & & & & & $\mathrm{W}$ & $201 \mathrm{C} / \mathrm{T}$ & & & & & & & & & \\
\hline & W & \begin{tabular}{|l|}
322,324 \\
\end{tabular} & & & & & & W & $208 \mathrm{C} / \mathrm{T}$ & & & & & & & & & \\
\hline & & $\mathrm{CC} / \mathrm{GG}$ & & & & & & & & & & & & & & & & \\
\hline & W & $369 \mathrm{G} / \mathrm{C}$ & & & & & & W & $218,220,222$ & $219 \mathrm{C} / \mathrm{A}$ & $219 \mathrm{C} / \mathrm{G}$ & $219 \mathrm{C} / \mathrm{T}$ & $220 \mathrm{~A} / \mathrm{G}$ & $220 \mathrm{~A} / \mathrm{G}$ & $221 \mathrm{C} / \mathrm{A}$ & $221 \mathrm{C} / \mathrm{G}$ & & \\
\hline & & & & & & & & & CAA/GCC & & & & & & & & & \\
\hline & $\mathrm{W}$ & $412 \mathrm{~A} / \mathrm{C}$ & $413 \mathrm{~A} / \mathrm{G}$ & 419G/A & & & & W & $234 \mathrm{C} / \mathrm{G}$ & $234 \mathrm{C} / \mathrm{T}$ & $240 \mathrm{~T} / \mathrm{C}$ & & & & & & & \\
\hline & W & $425 \mathrm{~A} / \mathrm{C}$ & & & & & B & W & $505 \mathrm{C} / \mathrm{T}$ & & & & & & & & SM & B \\
\hline & W & $479 \mathrm{C} / \mathrm{T}$ & & & & & & W & $526 \mathrm{C} / \mathrm{T}$ & $527 \mathrm{~A} / \mathrm{C}$ & $527 \mathrm{~A} / \mathrm{T}$ & $530 \mathrm{C} / \mathrm{T}$ & & & & & & \\
\hline & W & 514G/A & & & & & & W & $920 \mathrm{C} / \mathrm{A}$ & $920 \mathrm{C} / \mathrm{G}$ & $921 \mathrm{~A} / \mathrm{G}$ & & & & & & & \\
\hline & $\mathrm{W}$ & $539 \mathrm{C} / \mathrm{A}$ & & & & & & $\mathrm{W}$ & $893 \mathrm{G} / \mathrm{A}$ & & & & & & & & & \\
\hline & W & $823 \mathrm{~A} / \mathrm{G}$ & & & & & & W & $134 \mathrm{~A} / \mathrm{G}$ & $134 \mathrm{~A} / \mathrm{C}$ & & & & & & & & \\
\hline & W & 944G/A & 944G/C & 944,945 & & & & W & $268 \mathrm{~A} / \mathrm{C}$ & $269 \mathrm{~A} / \mathrm{C}$ & $269 \mathrm{~A} / \mathrm{T}$ & & & & & & & \\
\hline & & & & $\mathrm{GC} / \mathrm{CA}$ & & & & & & & & & & & & & & \\
\hline & W & $982 \mathrm{~T} / \mathrm{G}$ & & & & & B & $\mathrm{W}$ & $1423 \mathrm{~A} / \mathrm{G}$ & $1424 \mathrm{C} / \mathrm{A}$ & $1424 \mathrm{C} / \mathrm{T}$ & & & & & & KM & B \\
\hline & W & $1431 \mathrm{G} / \mathrm{A}$ & & & & & & W & 1516G/T & & & & & & & & & \\
\hline & W & $1700 \mathrm{~T} / \mathrm{C}$ & & & & & $\mathrm{B}$ & W & $7868 \mathrm{~A} / \mathrm{G}$ & 7868A/C & $7870 \mathrm{G} / \mathrm{A}$ & $7870 \mathrm{G} / \mathrm{T}$ & $7870 \mathrm{G} / \mathrm{C}$ & & & & EB & B \\
\hline & W & $1778 \mathrm{G} / \mathrm{A}$ & & & & & B & $\mathrm{W}$ & $7940 \mathrm{~T} / \mathrm{G}$ & & & & & & & & & B \\
\hline B & Tub-P & Tub-N & avi-P & avi-N & acid-fast & B & & & & & & & & & & & & \\
\hline
\end{tabular}

Drug resistance genes were $i n h A$ and $K a t G$ (INH), $r p o B$ (RFP), rrs and $r p s L$ (SM), rrs (KM), and embB (EB). Tub-p, Tub-N, Avi-P and Avi-N indicates tuberculosis positive, negative, avidin positive, negative. Acid-fast indicates non-tuberculosis of acid fast. The site of B indicates position marker of each drugs mutation detection field on array. The microarray field is devided into INH, RFP, SM, KM, and EB resistance detection fields. When there are positive signal in the Tub-P and Avi-P spots, the sample contains M. tuberculosis and the DNA microarray test is valid.

Table 2. Antituberculous Drug Resistance Genes and the Role of them in the Resistance of M. tuberculosis.

\begin{tabular}{|c|c|c|c|}
\hline anti-TB drug & Drug resistance-related genes & $\begin{array}{c}\text { Importance of each gene } \\
\text { in anti-TB drug resistance }\end{array}$ & $\begin{array}{c}\text { DNA microarray coverage } \\
\text { of resistance genes }\end{array}$ \\
\hline INH & $i n h A, k a t G$ & $80 \%$ & $100 \%$ \\
\hline RFP & $r p o B$ & $95 \%$ & $100 \%$ \\
\hline SM & $r r s, r p s L$ & $80 \%$ & $100 \%$ \\
\hline KM & $r r s$ & $70 \%$ & $100 \%$ \\
\hline EB & $e m b B$ & $70 \%$ & $100 \%$ \\
\hline
\end{tabular}

Oligomers on the DNA microarray were arranged to detect all mutations of rpoB, inhA, KatG, rrs, rpsL, rrs, and emb B.

applied to a DNA microarray slide, covered with a coverslip, and hybridized at $42^{\circ} \mathrm{C}$ for $60 \mathrm{~min}$. After hybridization, the DNA microarray was washed in washing buffer A at $42^{\circ} \mathrm{C}$ for $20 \mathrm{~min}$ to remove excess biotin-labeled DNA probes. Hybridization signals were developed as black spots by the peroxidase method. The binding solution $(1.4 \mathrm{ml})$ was prepared from a kit according to the manufacturer's instructions, and was applied to the oligonucleotide spots on the DNA microarray, after which the microarray was incubated for $30 \mathrm{~min}$ at room temperature. Then the slide was washed twice with the coloring buffer for $5 \mathrm{~min}$ at room temperature. Next, $1.4 \mathrm{ml}$ of coloring solution was prepared from the same kit according to the manufacturer's instructions, drops of the solution were added to the DNA microarray, and incubation was done at room temperature for $30 \mathrm{~min}$.
Subsequently, the microarray was rinsed with distilled water and air-dried. All of the solutions and buffers for hybridization were supplied by Nisshinbo Industries, Inc. Black hybridization signals on the microarray were scanned using a standard OA scanner (GT-8700F, Epson, Tokyo, Japan) to provide signal intensity data for subsequent computer analysis.

\section{Drug sensitivity test using broth culture}

Homogenized sputum was treated with NALC-NaOH [12], and then inoculated into a Lowenstein-jensen standard culture-based drug sensitivity testing system raised in recommended drug concentrations for drug susceptibility testing as described [8] according to the manufacturer's instructions (Mycosensitive spectrum-SR, Kyokuto, Tokyo, 
Table 3. Sensitivity and Specificity of DNA Microarray Analysis in M. tuberculosis Sputum Sample.

\begin{tabular}{|c|c|c|}
\hline anti-TB drug & sensitivity $(95 \% \mathrm{CI})$ & specificity $(95 \% \mathrm{CI})$ \\
\hline INH & $0.91(0.77-0.97)$ & $0.60(0.30-0.88)$ \\
\hline RFP & $0.97(0.82-1.0)$ & $0.95(0.75-1.0)$ \\
\hline SM & $0.93(0.80-1.0)$ & $0.73(0.4-0.94)$ \\
\hline KM & $0.96(0.85-1.0)$ & $0.67(0.22-1.0)$ \\
\hline EB & $0.98(0.87-1.0)$ & $0.89(0.52-1.0)$ \\
\hline
\end{tabular}

The sensitivity and specificity were calculated by assuming that the culture-based method of Lowenstein-jensen drug sensitivity test was correct. The number of samples tested for each drug (wild/mutant) was as follows: INH (38/10), RFP (28/20), SM (40/8), KM (44/4), and EB (39/9).

Japan). The cut-off values for each drug were as follows: INH $(0.2 \mu \mathrm{g} / \mathrm{ml})$, RFP $(40.0 \mu \mathrm{g} / \mathrm{ml}), \mathrm{SM}(10 \mu \mathrm{g} / \mathrm{ml}), \mathrm{KM}$ $(20 \mu \mathrm{g} / \mathrm{ml})$, and $\mathrm{EB}(2.5 \mu \mathrm{g} / \mathrm{ml})$ [11]. The result of drug resistant patient's number based on culture method were followings (wild/mutant); INH (38/10), RFP (28/20), SM (40/8), KM (44/4) and EB (39/9).

\section{Grading of sputum smears}

To grade the quantity of $M$. tuberculosis bacilli in sputum smears, carbolfuchsin staining was performed. Stained smears were examined by microscopy (Olympus BX50F4) of high power field (HPF) of $\times 200$, and scored according to the quantitation scale for AFB smears. Criteria for grading the quantity of $M$. tuberculosis bacilli were according to the method reported in the official statement of the ATS and CDC [11].

\section{Amplification of H37Rv M. tuberculosis DNA}

DNA from the laboratory strain M. tuberculosis H37Rv was isolated using phenol-chloroform and ethanol, and was employed as the positive control on gel electrophoresis. M. tuberculosis DNA from sputum samples and H37Rv was diluted $(1,10,100,1000,10000,10000)$ in TE buffer, and the 85A gene (a M. tuberculosis-specific gene) was amplified by PCR. The PCR master mix contained $2 \mu \mathrm{l}$ of $10 \times$ PCR buffer with $15 \mathrm{mM} \mathrm{MgCl}_{2}, 1.6 \mu \mathrm{l}$ of $2.0 \mathrm{mM}$ dNTP, $2 \mu \mathrm{l}$ of $25 \mathrm{mM} \mathrm{MgCl}_{2}, 7.6 \mu \mathrm{l}$ of distilled water, and $0.2 \mu \mathrm{l}$ of AmpliTaqGold. Then $1 \mu \mathrm{l}$ of HRv37 DNA was added, as well as $100 \mathrm{pmol}$ of the primers for the $85 \mathrm{~A}$ gene (U; 5' CCGCGGGGGCATTTTC 3', L; 5' GCTCCCGCGTAGACGAACT 3'), and amplification was done. PCR started with denaturation for $9 \mathrm{~min}$ at $95^{\circ} \mathrm{C}$, followed by 50 cycles of $30 \mathrm{~s}$ at $94^{\circ} \mathrm{C}$ and $1 \mathrm{~min}$ at $64^{\circ} \mathrm{C}$, as well as $10 \mathrm{~min}$ at $72^{\circ} \mathrm{C}$ for extension using an $\mathrm{ABI}$ prism 3300 (PE Biosystems Ltd.).

\section{Statistical analysis}

The accuracy of the DNA microarray for detecting resistance was calculated from the sensitivity (true positive rate) and specificity (true negative rate) of $95 \%$ confidence intervals (CI). Specimens that were positive by both methods were defined as true positive and specimens negative by both methods were defined as true negative.

\section{Results}

The drug resistances of $M$. tuberculosis isolated from sputum samples were evaluated by culture-based method of Lowenstein-jensen drug sensitivity testing system and DNA microarray analysis, and both results were compared. DNA microarray analysis of resistance to RFP, SM, and KM is shown in Figure 1a and 1b. The test was performed on 48 samples, and the result of the sensitivity of DNA microarray diagnosis was high $(>90 \%)$ for all five antituberculous drugs. The specificity for RFP and EB was also high, being $>95.0 \%$ and $89.0 \%$, respectively, by DNA microarray diagnosis. However, specificity for INH, SM, and KM was only $60.0 \%, 73.0 \%$, and $67.0 \%$, respectively.

To investigate the reasons for the discrepancy between culture-based and DNA microarray methods, we performed sequencing of sputum DNA samples. Sequence analysis was performed as previously [10]. Mutant type by DNA microarray analysis on sputum sample showed mutant by sequence analysis (data not shown). Colonies samples from these sputum samples showed wild type by cultured-based drug resistance test. In addition, we harvested the colonies grown in culture of the sputum specimens, and purified DNA from those colonies was subjected to DNA microarray analysis. When the colonies samples were used for DNA microarray after cultured (i.e., not sputum), the result of culture based method and DNA microarray analysis were corresponded. Thus, after growth on culture, microarray analysis of colonies were corresponded with the culture-based method, appeared that the bacteria were supposed to be heterogeneous from those in the sputum as described [13].

Among the specimens that were mutant by the culturebased method but wild-type by microarray analysis, there were several samples with a low number of acid-fast bacilli (AFB) on smears of less than 1-9 AFB per 100 fields using carbolfuchsin stain. To determine the limit of detection by 


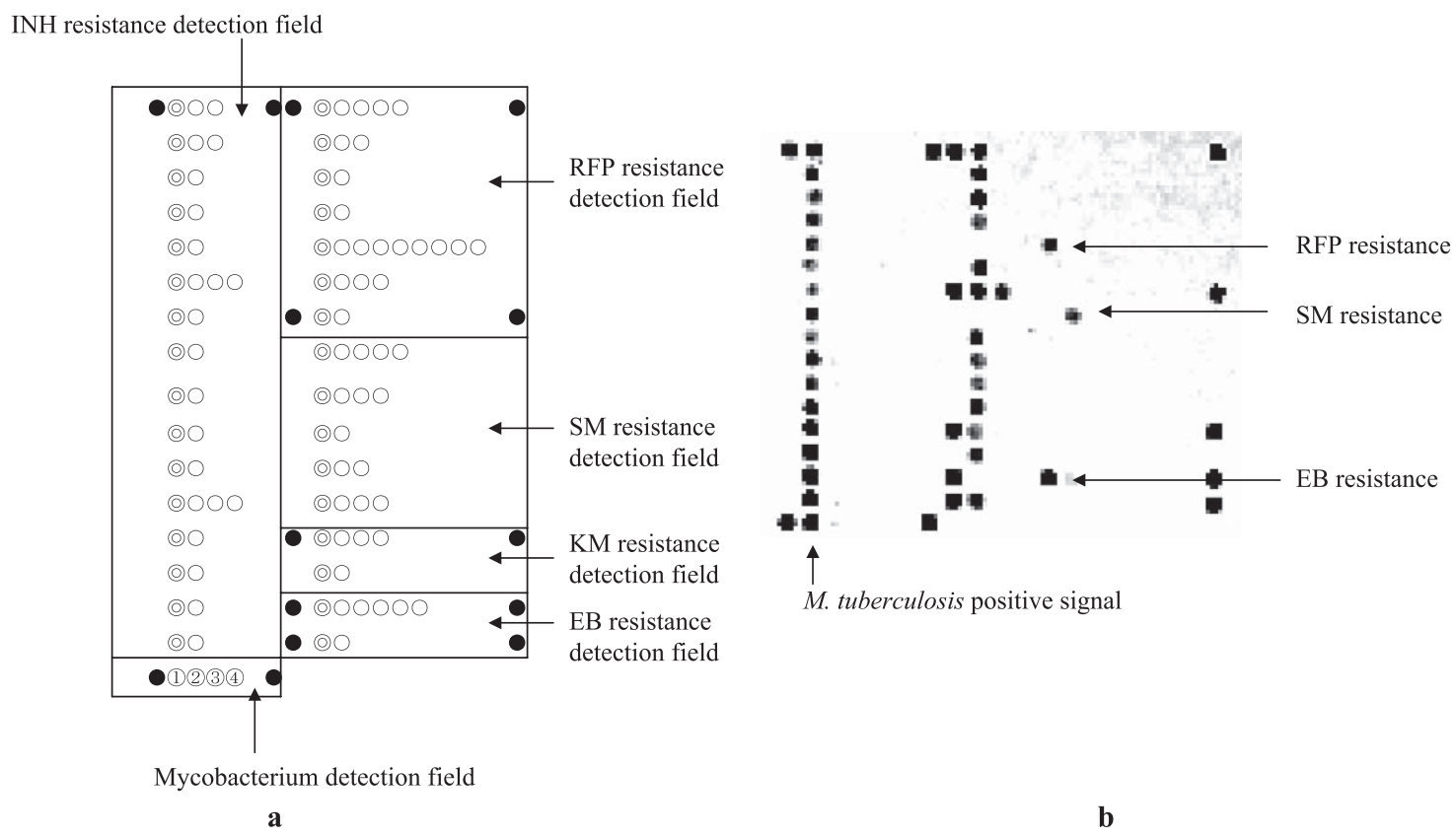

Fig. 1. a. Explanation of the DNA microarray. The array was divided into six fields. Black circles are position markers for biotinylated oligomers in each fields. Double circles are wild-type and single circles are mutant. b. The result of DNA microarray analysis of sputum with RFP, SM, and KM resistance.

DNA microarray analysis for smear grades, we performed PCR for the 85A gene of M. tuberculosis obtained from sputum samples and the pure genome of H37Rv M. tuberculosis strain. A PCR for the 85A gene showed that the limit of DNA microarray analysis was 10-20 AFB per 100 fields in sputum samples including AFB and $10^{4}$ bacilli for the H37Rv genome. These results showed that at least 1-9 AFB per 10 fields on carbofuchsin staining was needed.

\section{Discussion}

The present study revealed that a DNA microarray method showed good sensitivity in five drugs of INH, RFP, SM, KM and EB (>90\%) and specificity in RFP (95\%) and EB (89\%) for distinguishing wild-type from mutant $M$. tuberculosis in patient sputum samples. Signals on the DNA microarray could be easily viewed with an office scanner, however, at least 1-9 AFB (i.e., M. tuberculosis bacilli) per 10 fields on carbolfuchsin staining of amount of bacilli were needed to prevent misunderstandings in microarray.

There were several possible reasons for the difference in results between the culture-based method and the DNA microarray. DNA microarray could detect mutant correctly, when the M. tuberculosis DNA after growing in culture was applied to DNA microarry, that is, the results of drug resistant analyzed by culture-based method and the result of DNA microarry was corresponded in analysis from the M. tuberculosis DNA after growing in culture. However, in several M. tuberculosis DNA samples isolated from sputum, the results of drug resistant analyzed by culture-based method and the result of DNA microarray were not corresponded. Possible reason was reported that heterogeneity of resistance in sputum sample could be affected the discrepancy between culture-based method and DNA microarray analysis [13]. The meta-analysis of accuracy of LiPA showed that LiPA was a highly sensitive and specific test for the detection of RIF resistances in culture isolates. However, the test was also reported that it appeared to have lower sensitivity when used directly on clinical specimens as our DNA microarray [5]. Prediction of drug-resistant genotypes of mycobacterium found after cultivation not always give a good reflection of those in the original clinical sample. Further analysis was needed whether this matter occurred or not in our study. From the analysis of present study of needed amount of M. tuberculosis bacilli using H37Rv genome and sputum sample genome from $M$. tuberculosis patients, to minimize misunderstandings in microarray, we found that at least 1-9 AFB (i.e., $M$. tuberculosis bacilli) per 10 fields on carbofuchsin staining were needed to in our microarray analysis. There was another possible reason for the culture-based method showing mutant DNA and the microarray showing the wildtype. Present DNA microarray was not prepared with primers and spots for mutations of KasA and $\operatorname{ahpC}$ (INH) or $e m b A$ and $e m b C$ (EB) [9]. If M. tuberculosis contained these genes, they would not be amplified by PCR of DNA directly isolated from sputum, and these genes would confer resistance in the culture-based method. This specimen possibly 
shows mutant by the cultured-based method, nevertheless wild-type by the DNA microarray method. To improve specificity, it will be necessary to devise suitable primers and add spots for these genes to the DNA microarray in the future.

Taken together, to minimize misunderstandings on DNA microarray, it will be necessary to obtain bacteria equivalent to at least 1-9 AFB per 10 fields on carblofuchsin staining, as well as using the culture-based method for confirmation.

In conclusion, drug resistance genes detection using DNA microarray appeared to be useful, however, direct application of $M$. tuberculosis DNA from the sputum to DNA microarray has a risk of misdiagnosis. It is thus necessary to carefully select the conditions for use of such methods.

\section{Acknowledgements}

The authors thank Tsugio Nakazawa Prof. of Gunma University School of Health Sciences, for advice on the study design, and Mitsushige Hirano for assistance with manuscript preparation. This study was not supported by any grants. None of declares for present study.

\section{References}

[1] Zumla, A. and Grange, J.M.: Multidrug-resistant tuberculosis - can the tide be turned? Lancet. Infect. Dis., 1, 199202, 2001.

[2] Troesch, A., Nguyen, H., Miyada, C.G., Desvarenne, S., Gingeras, T.R., Kaplan, P.M., Cros, P., and Mabilat, C.: Mycobacterium species identification and rifampin resistance testing with high-density DNA probe arrays. J. Clin. Microbiol., 37, 49-55, 1999.

[3] Head, S.R., Parikh, K., Rogers, Y.H., Bishai, W., Goelet, P., and Boyce-Jacino, M.T.: Solid-phase sequence scanning for drug resistance detection in tuberculosis. Mol. Cell Probes, 13, 81-87, 1999.

[4] Cooksey, R.C., Holloway, B.P., Oldenburg, M.C., Listenbee, S., and Miller, C.W.: Evaluation of the invader assay, a linear signal amplification method, for identification of mutations associated with resistance to rifampin and isoniazid in Myco- bacterium tuberculosis. Antimicrob. Agents Chemother, 44, 1296-1301, 2000.

[5] Morgan, M., Kalantri, S., Flores, L., and Pai, M.: A commercial line probe assay for the rapid detection of rifampicin resistance in Mycobacterium tuberculosis: a systematic review and meta-analysis. BMC. Infect. Dis., 5, 62, 2005.

[6] Banerjee, A., Dubnau, E., Quemard, A., Balasubramanian, V., Um, K.S., Wilson, T., Collins, D., de, Lisle., and Jacobs, W.R.: inhA, a gene encoding a target for isoniazid and ethionamide in Mycobacterium tuberculosis. Science, 263, 227-230, 1994.

[7] Zhang, Y., Heym, B., Allen, B., Young, D., and Cole, S.: The catalase-peroxidase gene and isoniazid resistance of Mycobacterium tuberculosis. Nature, 358, 591-593, 1992.

[8] Telenti, A., Honore, N., Bernasconi, C., March, J., Ortega, A., Heym, B., Takiff, H.E., and Cole, S.T.: Genotypic assessment of isoniazid and rifampin resistance in Mycobacterium tuberculosis: a blind study at reference laboratory level. $J$. Clin. Microbiol., 35, 719-723, 1997.

[9] Ramaswamy, S. and Musser, J.M.: Molecular genetic basis of antimicrobial agent resistance in Mycobacterium tuberculosis. Tuber. Lung. Dis., 79, 3-29, 1998.

[10] Shimizu, Y., Dobashi, K., Mita, Y., Endou, K., Moriya, S., Osano, K., Koike, Y., Higuchi, S., Yabe, S., Utsugi, M., Ishizuka, T., Hisada, T., Nakazawa, T., and Mori, M.: DNA microarray genotyping of $\mathrm{N}$-acetyltransferase 2 polymorphism using carbodiimide as the linker for assessment of isoniazid hepatotoxicity. Tuberculosis, 86, 374-381, 2006.

[11] This Official Statement of the American Thoracic Society and the Centers for Disease Control and Prevention was Adopted by the ATS Board of Directors, July 1999.: Diagnostic Standards and Classification of Tuberculosis in Adults and Children. Am. J. Respir. Crit. Care Med., 161, 1376-1395, 2000.

[12] Ratnam, S., Stead, F.A., and Howes, M.: Simplified acetylcysteine-alkali digestion-decontamination procedure for isolation of mycobacteria from clinical specimens. J. Clin. Microbiol., 25, 1428-1432, 1987.

[13] Rinder, H., Mieskes, K.T., and Loscher, T.: Heteroresistance in Mycobacterium tuberculosis. Int. J. Tuberc. Lung. Dis., 5, 339-345, 2001. 